Research Article

\title{
Load Transfer Characteristics of a Cable Bolt in DEPT
}

\author{
Xuwei Li $\mathbb{D I}^{1,2}$ \\ ${ }^{1}$ Key Laboratory of Deep Coal Resource Mining (China University of Mining \& Technology), Ministry of Education, \\ Xuzhou 221116, Jiangsu, China \\ ${ }^{2}$ School of Mines, China University of Mining and Technology, Xuzhou 221116, Jiangsu, China \\ Correspondence should be addressed to Xuwei Li; lixuwei129242@126.com
}

Received 20 September 2019; Accepted 21 October 2019; Published 6 November 2019

Academic Editor: Mickaël Lallart

Copyright (c) 2019 Xuwei Li. This is an open access article distributed under the Creative Commons Attribution License, which permits unrestricted use, distribution, and reproduction in any medium, provided the original work is properly cited.

\begin{abstract}
Cable bolts help surrounding rock masses of underground excavations to form internal rock structure and thus self-stabilize through effective load transfer between rock masses and cable bolts. The load transfer characteristics of cable bolt play the most significant role in cable selection for support design. There are many factors potentially affecting the load transfer characteristics of cable bolt via strengthening or weakening load contributors such as cable bonding, mechanical interlocking, frictional resistance at cable-grout interface and grout-rock interface, and shearing of grout anchorage. Double embedment pull test (DEPT) is an effective, reliable, and repeatable test method of investigating the load transfer characteristics of cable bolt and thus was selected in this study. With DEPT, the influence of factors such as cable rotation, grout age, grout anchorage annulus thickness, cable wire profile, and failure mode on the load transfer characteristics of cable bolt were investigated in terms of tensile strength and stiffness in different loading stages. Conclusions drawn from the study can be used to improve cable installation quality and to select appropriate cable bolting technique.
\end{abstract}

\section{Introduction}

Bolting is currently the most commonly accepted rock reinforcement method of dealing with rock strata instability in both surface and underground mines as well as in civil engineering. Bolts are installed in fractured rock mass to build composite beams in weak strata and/or to attach weak excavation surfaces to deeper and competent rock layers to achieve stability [1]. Bolts used in mines can be simply divided into rock bolt and cable bolt. Rock bolt is a type of solid tendon which can normally reach a reinforcement depth of less than $2.5 \mathrm{~m}$, whereas cable bolt consists of twisted strands which can reach a reinforcement depth of more than $4 \sim 6 \mathrm{~m}$. In some countries, multiple solid rock bolts are connected by connecting sleeves to form a long solid rock bolt. However, this type of connected long solid rock bolt is not popular due to its complexity in installation when used in narrow underground roadways $[2,3]$. Due to the structural difference, the cable bolt and rock bolt behave differently in reinforcing rock masses.
After opening, rock mass around the excavation space experiences stress redistribution, and correspondingly, rock fracturing occurs in this process. Bolts installed in the fractured rock mass around excavations normally bear combined tensile and shear loads due to the opening and sliding of shear planes and bed separations. Direct shear restraint and high normal stress are applied by bolt to fracture surfaces to minimize their displacements. This mechanism allows excavation surfaces to stabilize and makes them self-supporting $[4,5]$. In order to mobilize the shear restraint and high normal stress, loads have to be effectively transferred between cable bolts and rock masses mainly via the grout anchorage [6]. The quality of the internal grout anchorage determines the performance of cable bolt and the final peak load cable bolts could take before failure. Thus, it is of great importance to assess the tensile performance of cable bolts for better selection in support design.

Quite a few facilities have been developed in the past to investigate the tensile performance and load transfer characteristics of cable bolts. The earliest test facility was a 
"split-pull" device designed by Fuller and Cox [7]. They used the device to study the effect of cable surface geometry and wire indentation on the load transfer of cable bolt. A similar test rig was designed by Goris and Conway [8], and the impact of epoxy coating on the peak bearing capacity of cable bolt was investigated. In 1991, Reichert [9] modified the traditional pull test device to form a "split-push" test device, with which the radial confinement effect was studied [9-11]. Stating that previous test facilities were designed with constant normal stiffness condition, which ignores another possible condition of constant radial pressure, Macsporran [12] incorporated a modified Hoek cell to produce the constant radial pressure. Stillborg [13] used concrete blocks to represent rock masses, with which short and long single embedment pullout tests were carried out and multiple influencing factors were studied. Hutchison and Diederichs [14] developed a double embedment pull test (DEPT) facility to investigate the load transfer characteristics of birdcage cable bolt. The shortcoming of this facility is that it cannot properly simulate the real grout-rock interaction as existing in field conditions. Thomas [15] modified the laboratory short encapsulation pull test facility which was initially developed by Clifford et al. [16] and investigated the performance of 14 different cable bolts commonly used in Australian coal mines. Most recently, Australian Coal Association Research Program (ACARP) funded to develop a new laboratory short encapsulation test facility, with which the impact of concrete strength, borehole diameter, and embedment length were investigated [17]. All the above developed facilities and methods together helped gradually uncover the tensile performance of cable bolt. The early methods are simpler, but cannot simulate real field conditions. However, the more recent methods can better simulate field conditions, but with more complexity in sample preparation and testing. In research, an appropriate method can be selected from the above methods with consideration of time, accuracy, and engineering condition.

DEPT is a simple repeatable test method, which is capable of investigating the influence of cable bolt, cable-grout interface, and grout quality on the overall performance of cable bolt in tension. In addition, the rotation effect of cable bolt in tension can be studied as well with an antirotation steel sleeve and a rotator. The main disadvantage of the DEPT method is that grout-rock interface cannot be simulated, and thus, its influence on cable's tensile performance cannot be investigated due to the absence of rock mass (concrete in laboratory tests). In addition, as the steel mould is of high stiffness, high confining stress is expectedly generated in the pullout process due to grout dilation. In spite of this, the DEPT method is suitable for this study as it allows a quick investigation of cable rotation, grout age, grout anchorage annulus thickness, cable wire profile, and failure mode, which is exactly the focus of this research. Thus, the DEPT method was selected in this study to investigate the general performance of cable bolt in tension. A series of DEPTs were conducted to study the influence of cable wire profile, grout age, cable rotation, failure mode, and anchorage annulus thickness on cable tensile performance in terms of stiffness and strength.

\section{DEPT Methods}

2.1. DEPT Apparatus. The basic components of the DEPT apparatus used in this study are given in Figure 1. A DEPT test apparatus comprises two embedment moulds, with each embedment mould consisting of two half blocks of steel mould with semicircular holes carved out in the middle. The two half blocks are butted together and bolted tightly using allen socket head bolts to form one embedment mould. The embedment mould has a central hole of designed diameter and length. The internal surface of the central hole has $2 \mathrm{~mm}$ deep grooves at a spacing of $10 \mathrm{~mm}$. The objective of designing these internal grooves is to allow effective anchorage of grout to the steel mould. The two embedment moulds were connected by a cable bolt in tension to form a DEPT sample.

A $9 \mathrm{~mm}$ thick rectangular steel sleeve was inserted on the assembled embedment apparatus to avoid rotation of the anchored cable bolt during the pullout process. A long window was cut on one side of the steel sleeve for checking the cable bolt section pulled out from the embedment mould as shown in Figure 1. As the steel embedment mould was clutched at its end by the machine jig, it was difficult for the cable bolt to rotate during the pullout process. The use of this steel sleeve was for double security.

A steel rotator was added to one end of the DEPT apparatus to allow the occurrence of cable rotation when investigating cable rotation effect. The rotator consists of a $150 \mathrm{~mm}$ long circular steel sleeve with thick wall and a $140 \mathrm{~mm}$ long steel bolt. The circular steel sleeve was threaded internally to match with the threads on the end section of the embedment mould. The steel bolt was inserted into the circular steel sleeve and clutched by the machine jig, and rotation was allowed between the steel bolt and the circular steel sleeve during the testing process. In other words, the circular steel sleeve will rotate together with the embedment mould when torque is built in the cable bolt, while the steel bolt held by the machine jig will stay still. Rotation occurs between the circular steel sleeve and the steel bolt.

\subsection{Sample Preparation and Testing Procedure. The prepa-} ration of a DEPT sample was to anchor a cable bolt into the two embedment moulds with designed anchorage length at two ends. The cable anchorage was finished in two steps in general: the upper end anchorage plus the lower end anchorage.

To anchor a cable bolt to the predesigned length, a steel disc was put in the central hole of the embedment mould to help position the anchorage length. Then, the embedment mould was bolted by allen socket head bolts and erected on ground. Grout was thoroughly mixed in a plastic bucket and poured into the embedment mould to fill half of the central hole. Then, slowly spin the cable bolt into the embedment mould until reaching the steel disc trapped in the central hole. When the cable bolt was in position, hit the ground lightly with the embedment mould to get the trapped air out of the grout. At last, remove the grout squeezed out from the central hole and clean the top end of the embedment mould. A steel ring was inserted on the cable bolt to help position it 


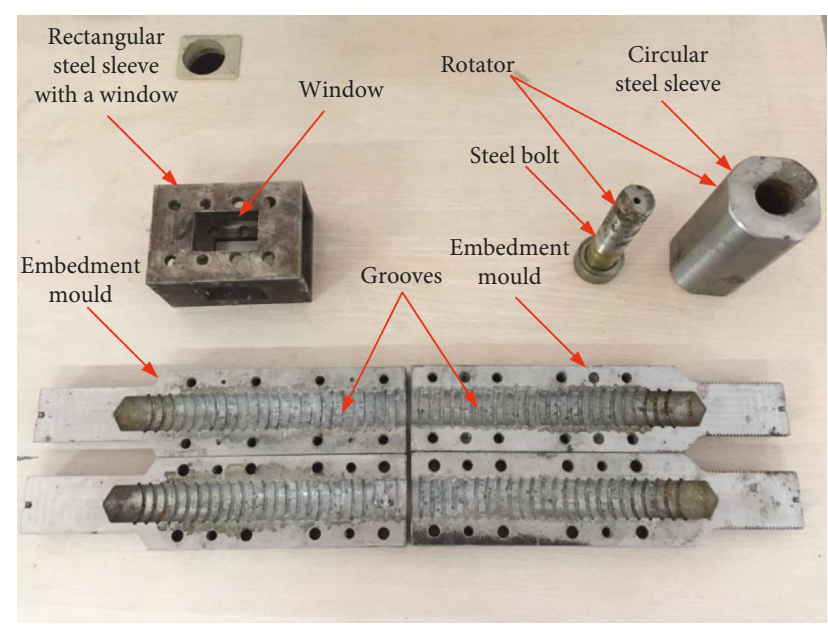

Figure 1: Main components of the DEPT apparatus.

to the center of the hole. The finished embedment mould was normally left to cure for one day before anchoring the other end. When anchoring the other end of the cable bolt, the same operation process was followed.

When the prepared samples were ready for testing, they were installed onto a MTS-815 testing machine with the sample ends gripped by the top and bottom jigs of the machine. In the whole testing process, the tested sample was loaded at a constant speed of $2 \mathrm{~mm} / \mathrm{min}$ until an obvious residual strength was reached. The pullout force and displacement were recorded and visualized by load cells and LVDTs integrated in the testing machine. An over view of the MTS-815 testing machine is given in Figure 2.

\section{Results and Discussion}

3.1. Basic Load Transfer Characteristics of Plain Cable Bolt in $D E P T$. A typical load-displacement relationship of a plain cable bolt tested with DEPT facility is given in Figure 3. In general, the cable load-displacement relationship can be divided into three stages: the linear stage, softening stage one (SS1), and softening stage two (SS2). In the initial linear stage, as there is no obvious rigid cable movement, the tensile stiffness is very high, which normally is more or less than $1 \mathrm{~mm}$. The high stiffness in the initial linear stage might be mainly attributed to the cohesive strength of cable-grout interface. Then, after the initial linear stage, the cable tensile stiffness starts to decrease gradually until a sharp force drop which normally occurs at a displacement of about $3 \sim 6 \mathrm{~mm}$. The gradual decrease in the cable tensile stiffness is supposed to be due to the plastic deformation of grout and grout crushing at the cable-grout interface. The sharp force drop might be attributed to the full crushing of grout bulges between cable wires and refitting of cable wires with the adjacent grout pits. After the sharp force drop, the cable bolt enters the second softening stage in which the cable tensile stiffness further decreases gradually until the peak tensile load is reached at a displacement of normally more than $40 \mathrm{~mm}$. In the second softening stage, the increase of tensile force is primarily from the frictional resistance of cable-

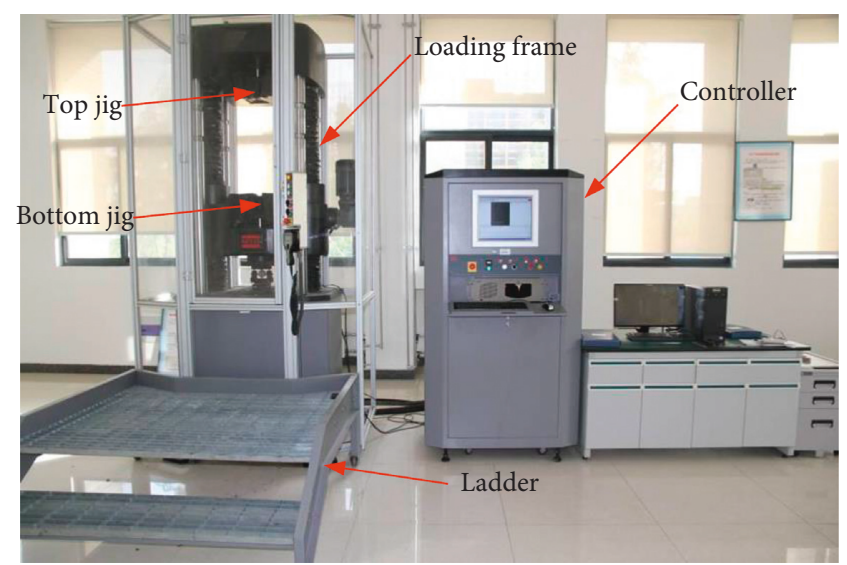

FIgURE 2: An over view of the MTS-815 testing machine used in the tests.

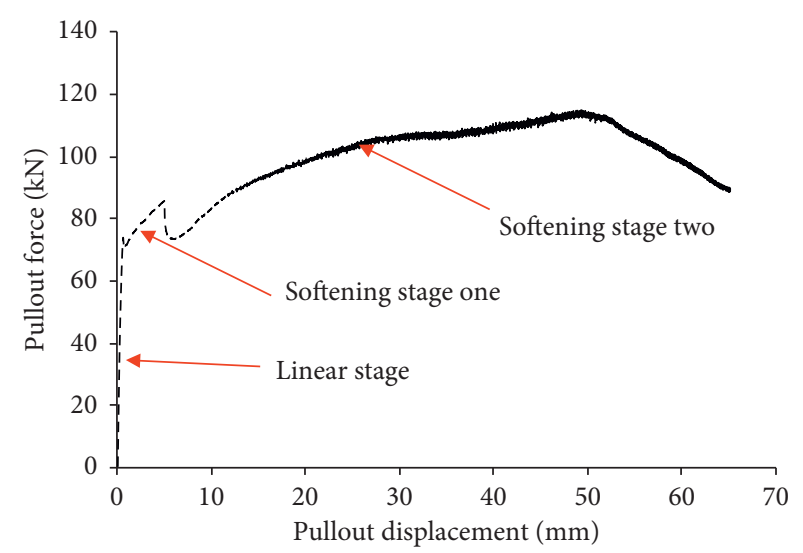

FIgUre 3: Typical load-displacement relationship of a plain cable bolt in DEPT.

grout interface, whereas the mechanical interlocking effect is weakened and does not contribute much to the increase of tensile force.

When pulled out from steel moulds, the cable bolt will take loads and tends to move relative to grout anchorage. In the pullout process, the pullout force is mainly attributed to contributors such as cable bonding, mechanical interlocking at cable-grout interface, frictional resistance at cable-grout interface, shearing of grout anchorage (if grout failure occurs), and frictional resistance at grout-mould interface (if failure occurs at grout-mould interface). The load transfer characteristics of cable bolt are thus controlled by these contributors in essence. Factors influencing these contributors can affect the overall load transfer characteristics of cable bolt. In the following section, the influence of such factors on the load transfer characteristics of cable bolt is systematically investigated. In the laboratory tests, three types of cable bolts were tested, and their specifications are given in Table 1.

3.2. Cable Rotation Effect. As cable bolt has a spiral structure, torque could be generated when a cable bolt is pulled out from anchorage. In field, the external anchorage (barrel and 
TABle 1: Specification of tested cable bolts.

\begin{tabular}{lccccc}
\hline Name & Profile & $\begin{array}{c}\text { Wire } \\
\text { no. }\end{array}$ & $\begin{array}{c}\text { Diameter } \\
(\mathrm{mm})\end{array}$ & $\begin{array}{c}\text { With modified } \\
\text { geometry }\end{array}$ & \multicolumn{1}{c}{ Comments } \\
$\begin{array}{l}\text { Traditional 7-wire cable bolt } \\
\text { used in China }\end{array}$ & Plain & 7 & 16 & No & $\begin{array}{c}\text { Tested to study cable rotation, failure } \\
\text { mode, and grout anchorage annulus } \\
\text { thickness }\end{array}$ \\
$\begin{array}{l}\text { Plain superstrand } \\
\text { Indented superstrand }\end{array}$ & Plain & 19 & 22 & No & $\begin{array}{c}\text { Tested to study cable wire profile, grout age, } \\
\text { and grout anchorage annulus thickness } \\
\text { Tested to study cable wire profile and grout } \\
\text { age }\end{array}$ \\
\hline
\end{tabular}

nut assembly and plate) is the controller and resister of this rotation, which influences the performance of cable bolt in tension. In the laboratory tests, a rotator was designed to allow the occurrence of cable rotation in order to investigate this effect. The setup of DEPT devices both with and without a rotator is given in Figure 4.

Though a rotator was used in the laboratory tests, it was still difficult to allow full rotation since friction existed in the rotator. Small rotation was seen in the test process, while a sudden large rotation was witnessed when the machine jig was loosened after tests, which indicated the remaining torque taken by the rotator due to friction.

Figure 5 shows the test results of two groups of plain cable bolts. For each group, cable bolts were anchored into DEPT moulds with the same grout mixture. Thus, cable bolts in each group should have similar grout anchorage quality, and thus, grout anchorage will not be a variable in these tests. Rotation is the only factor that could affect the load transfer performance of cable bolt in these DEPTs. As expected, DEPTs without a rotator produced higher pullout load than those with a rotator in general. The load difference in group $\mathrm{T} 1$ is much larger than that in group $\mathrm{T} 2$, which was probably attributed to the rotation degree in these two groups. In the testing process, the DEPT with a rotator experienced larger rotation in group T1 than in group T2 as shown in Figure 6. Except for the load difference, cable bolts exhibited similar load transfer characteristics in DEPTs both with and without a rotator. To be exact, both tests experienced the initial linear stage with high stiffness and the first and second softening stages with low stiffness. In addition, a noticeable force drop occurred prior to the second softening stage as always witnessed in other similar tests.

3.3. Grout Age Effect. The load transfer performance of a cable bolt in reinforcing rock masses is determined by cable bolt, grout, and rock mass. As for grout, deformability and strength are the two main influencing factors. As grout strength varies with curing time, the load transfer performance of cable bolt is thus potentially affected by the curing time of grout. The grout used in this study is Stratabinder HS, a cement product of Minova. In the product manual sheet provided by Minova, the strength of Stratabinder HS are $50 \mathrm{MPa}, 75 \mathrm{MPa}$, and $100 \mathrm{MPa}$ at ages of 1 day, 7 days, and 28 days, respectively. In order to investigate the grout age effect on the load transfer performance of cable bolt, a set of cable bolts were tested with DEPT devices at different grout ages. The test results are given in Figure 7.
It is seen from Figure 7 that the grout age effect on the load transfer performance of cable bolt was evident and consistent for both plain and indented cable bolts. Cable bolts with old grout exhibited higher strength in the whole testing process. Except for the strength, all the other load transfer characteristics of cable bolt were similar, such as basic loading profile, loading stiffness, and displacements at local force peak and final force peak. In other words, grout age mainly affected the anchoring strength of the cable bolt.

3.4. Grout Anchorage Annulus Thickness Effect. A cable bolt is grouted to the surrounding rock mass in field, and load and deformation is transferred between cable bolt and rock mass through the grout anchorage. The quality and dimension of the grout anchorage play a significant role in cable bolt reinforcement performance. Apart from grout age (strength), the grout anchorage thickness is another important influencing factor. Two different grout anchorage thicknesses were investigated in the laboratory tests. The thin grout anchorage annulus was $3 \mathrm{~mm}$, while the thick one was $8 \mathrm{~mm}$. Both the grout anchorage annuli were tested at an age of one week. The comparison of these two grout anchorage thicknesses can indicate the influence of grout anchorage thickness on cable bolt reinforcement performance. Figure 8 gives the test results of plain cable bolt with different anchorage annulus thicknesses.

In Figure 8, the cable bolt with thin grout anchorage annulus reached the local peak of $126 \mathrm{kN}$ at about $3 \mathrm{~mm}$, while the cable bolt with thick grout anchorage annulus yielded the local peak of $94 \mathrm{kN}$ at roughly $7.9 \mathrm{~mm}$. The average stiffness in the initial linear stage was much higher for the thin grout anchorage annulus than that for the thick grout anchorage annulus. Similarly, the same rule occurred to the final peak and the corresponding average stiffness in the second softening stage. To be specific, the final peak of $151 \mathrm{kN}$ was reached at about $46.3 \mathrm{~mm}$ for the thin grout anchorage annulus, whereas the final peak of $151 \mathrm{kN}$ was achieved at approximately $79.7 \mathrm{~mm}$ for the thick grout anchorage annulus. The impact of grout anchorage annulus thickness on cable bolt load transfer obtained in this study was the same as that found by Thomas [15]. What is worth noting is that the cable bolt with thin grout anchorage annulus was expected to produce higher final peak than the cable bolt with thick grout anchorage annulus. The reason why this did not occur is that the anchorage length of the cable bolt with thick grout anchorage annulus was $200 \mathrm{~mm}$, 


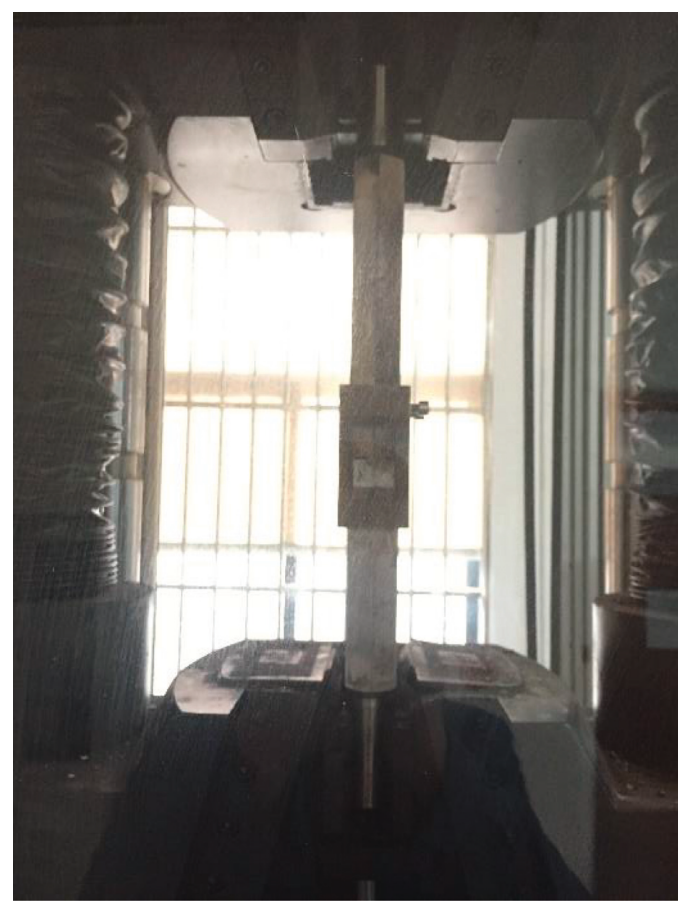

(a)

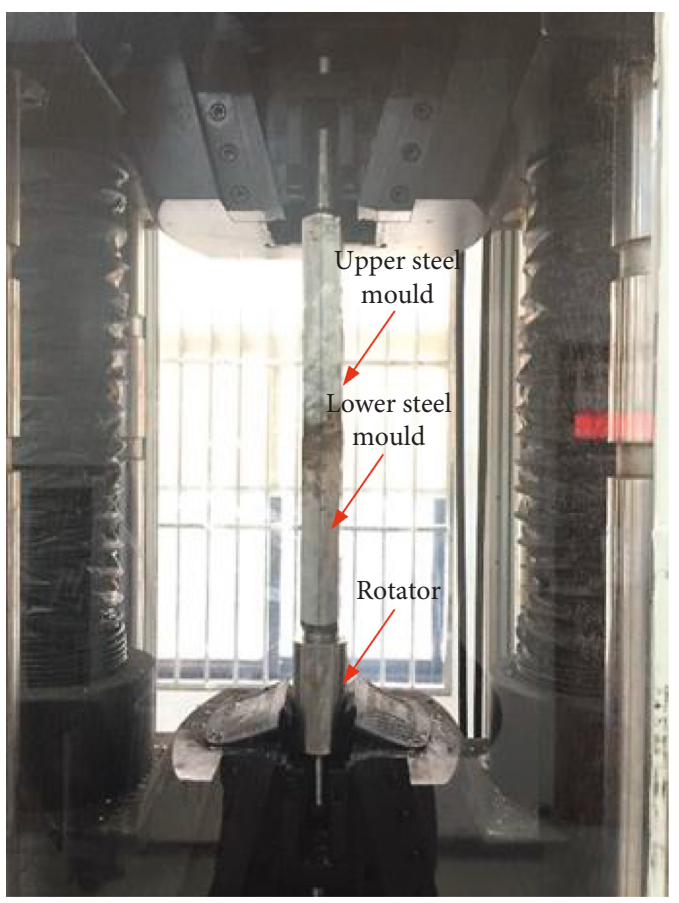

(b)

FIgURE 4: Setup of DEPT devices with and without a rotator.

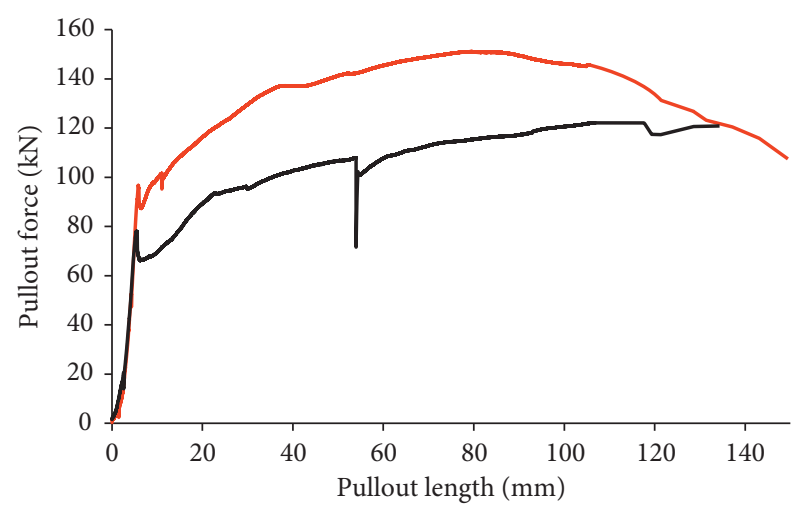

- T1_rotation
— T1_no rotation

(a)

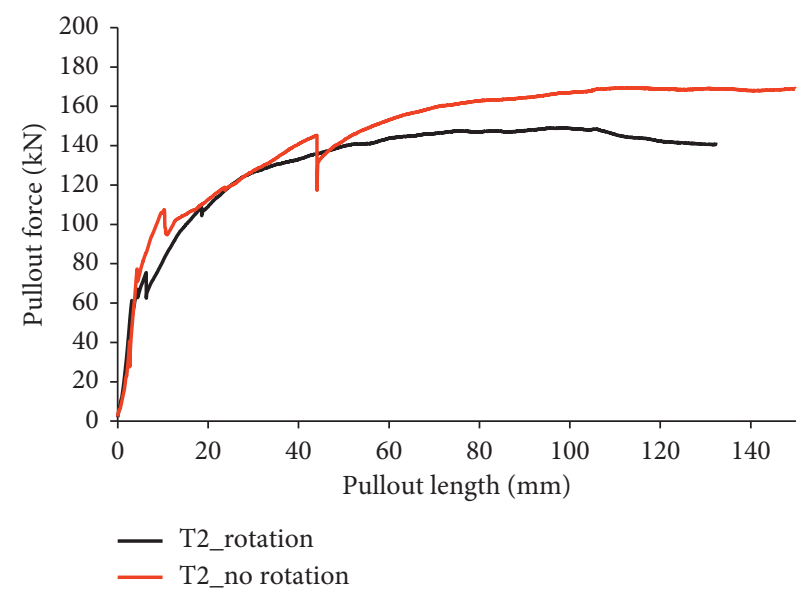

(b)

FIgure 5: Results of cable bolt in DEPTs with and without a rotator. (a) Test results of group T1. (b) Test results of group T2.

which was longer than that with thin grout anchorage annulus.

3.5. Cable Wire Profile Effect. Regarding the currently used cable bolts, there are two types in terms of their wire profile, i.e., plain/smooth wire and rough wire (indented or spirally ribbed). The aim of the rough wire profile is to increase friction and mechanical interlocking at the cable-grout interface, thereby increasing the corresponding resistance at the cable-grout interface. However, the change of wire profile not only increases the overall tensile resistance of the cable bolt but also changes its basic tensile characteristics. Plain and indented cable bolts of $22 \mathrm{~mm}$ diameter were tested in DEPT device with an inner diameter of $28 \mathrm{~mm}$. No rotator was used to allow the occurrence of cable rotation in the testing process. The test results of samples with different anchorage lengths and grout ages are given in Figure 9.

As for the plain cable bolt, the pullout force increased steeply in the initial $1 \sim 2 \mathrm{~mm}$ before slowly climbing to the local peak at about $3 \sim 6 \mathrm{~mm}$. Then, a sharp drop in force was normally followed by the local peak. After the force drop, the pullout force continued to increase at a small stiffness until 


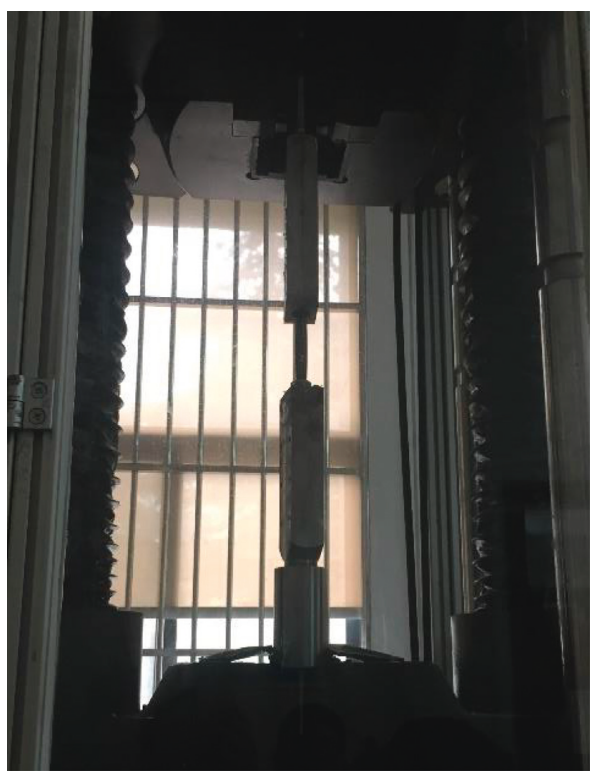

(a)

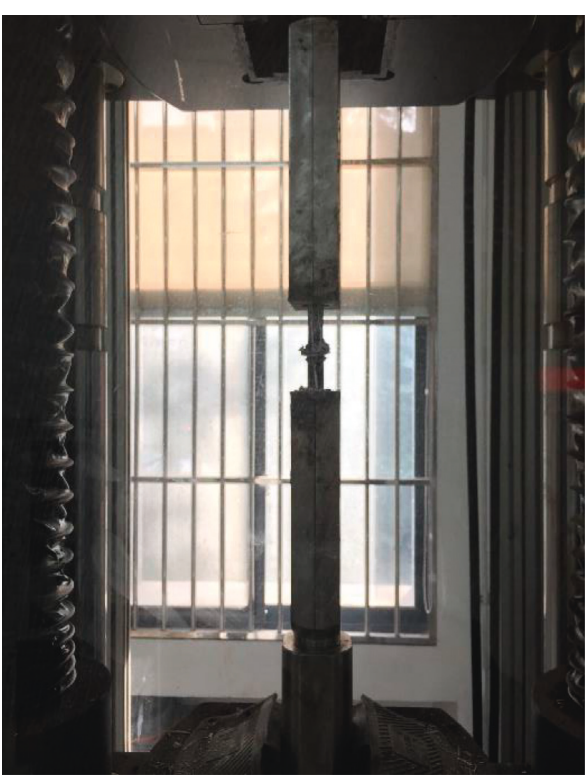

(b)

Figure 6: Cable rotation occurring in the testing process. (a) T1. (b) T2.

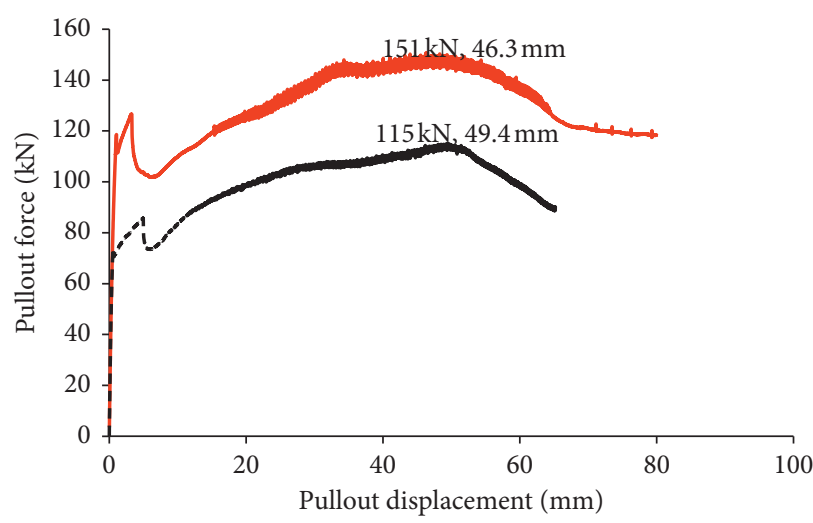

_ Plain $180 \mathrm{~mm}-1$ week

- - - Plain $180 \mathrm{~mm}-4$ days

(a)

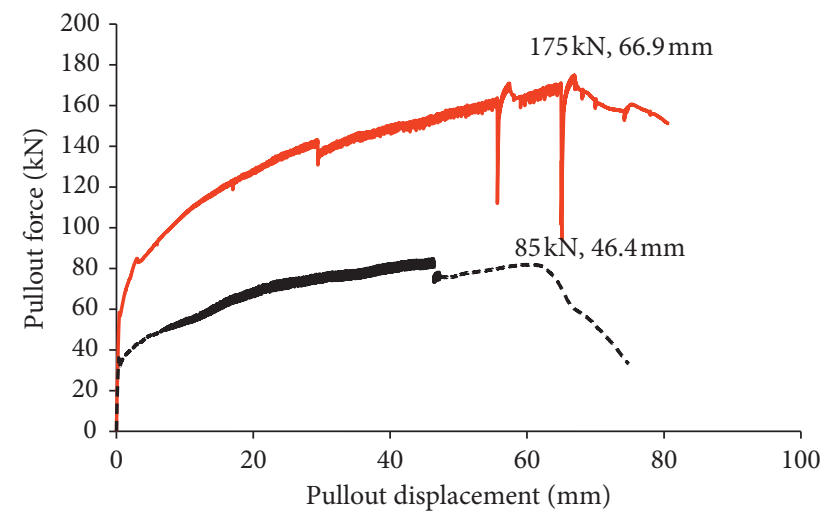

_ Plain $150 \mathrm{~mm}-3$ weeks

- - - Plain $150 \mathrm{~mm}-1$ week

(b)

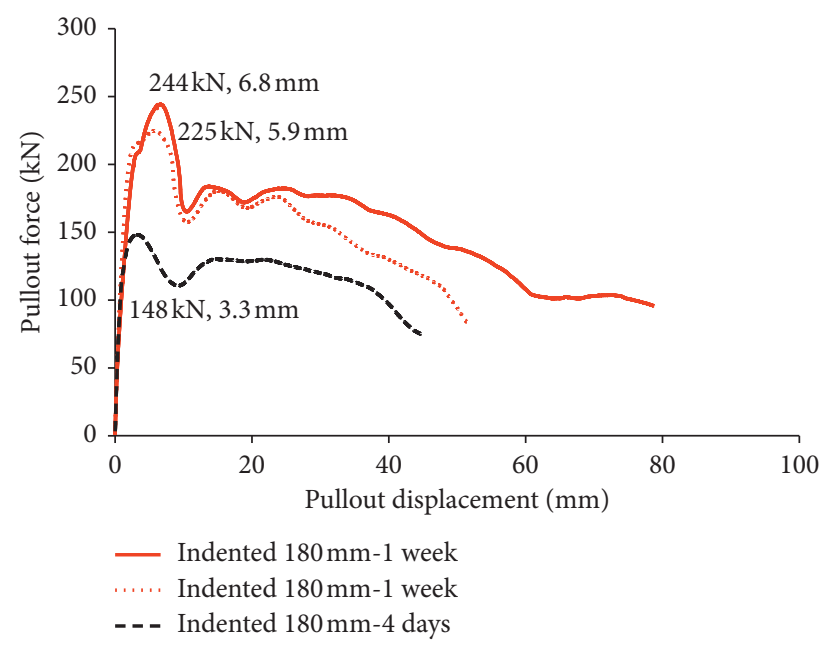

(c)

Figure 7: Results of cable bolts tested at different grout ages. (a) Plain cable bolt with $180 \mathrm{~mm}$ anchorage. (b) Plain cable bolt with $150 \mathrm{~mm}$ anchorage. (c) Indented cable bolt with $180 \mathrm{~mm}$ anchorage. 


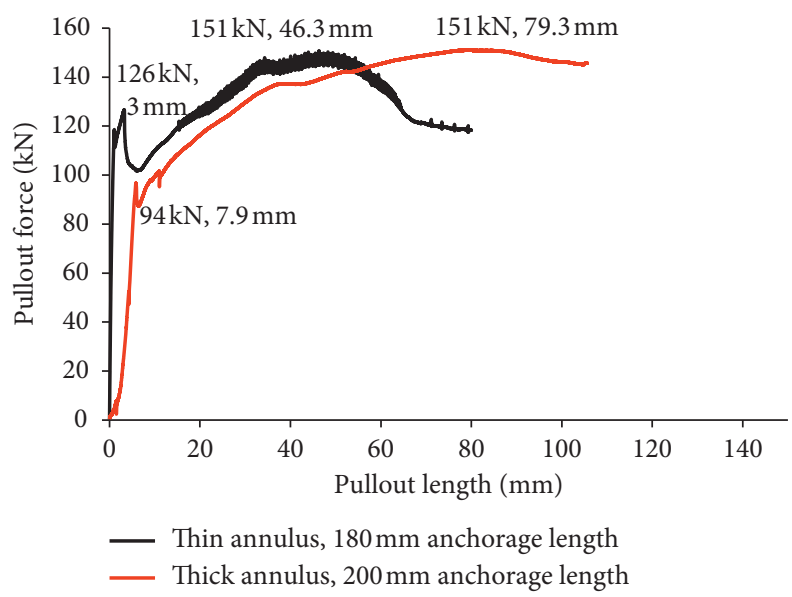

FIGURE 8: Performance of cable bolts tested with different grout anchorage annuli.

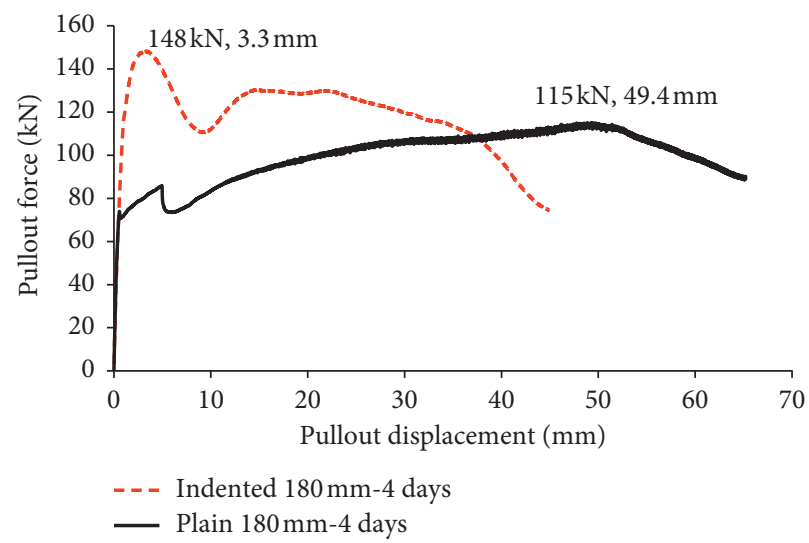

(a)

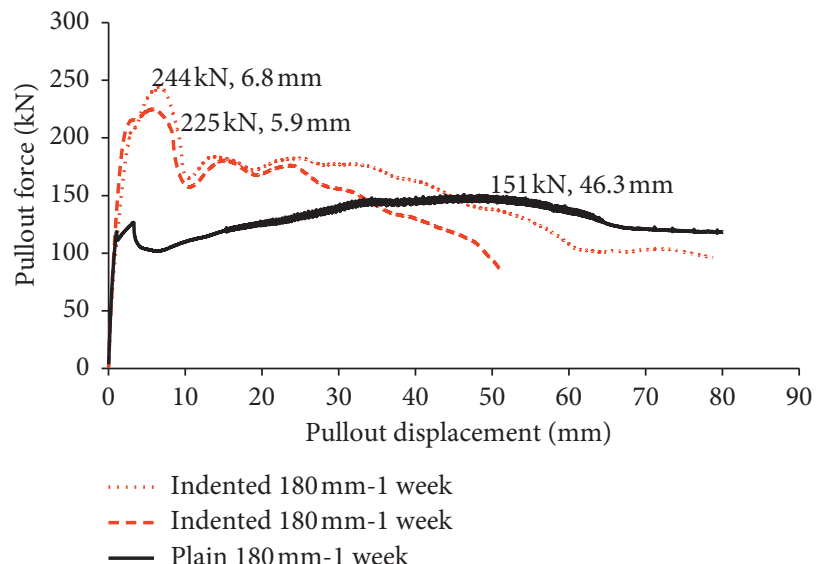

(b)

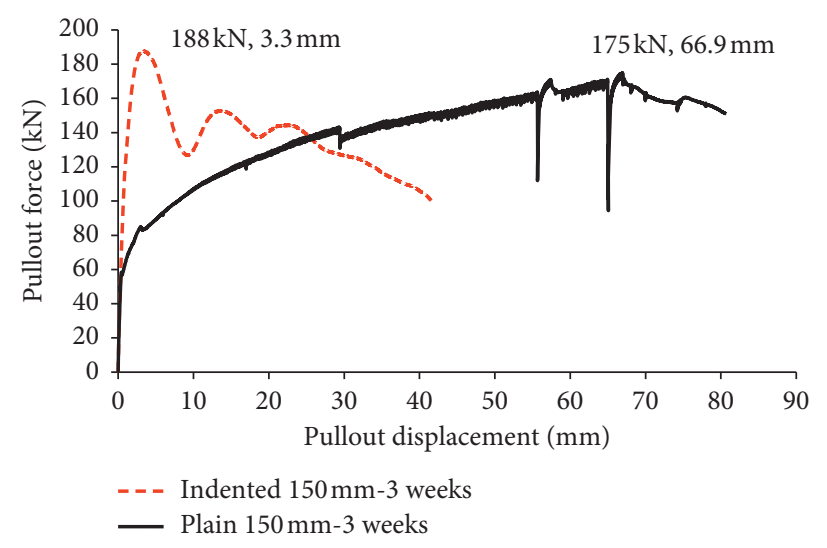

(c)

FIGURE 9: Load transfer characteristics of plain and indented cable bolts in DEPT. (a) 4-day-old samples with $180 \mathrm{~mm}$ anchorage. (b) 1week-old samples with $180 \mathrm{~mm}$ anchorage. (c) 3-week-old samples with $150 \mathrm{~mm}$ anchorage.

the final pullout strength and then decreased gradually to fully lose the tensile resistance.

Unlike the plain cable bolt, the indented cable bolt witnessed a steep increase in force followed by a short slow increase in force to the local peak at more or less the same pullout displacement as the plain cable bolt. Then, a force drop occurred, which was much gentler than the plain cable bolt. After the force drop, the pullout force picked up a little bit prior to gradually decreasing to fully lose the tensile resistance. 


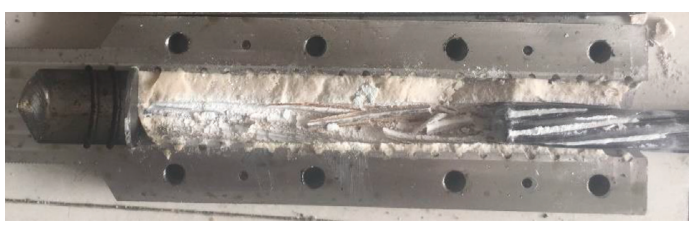

(a)

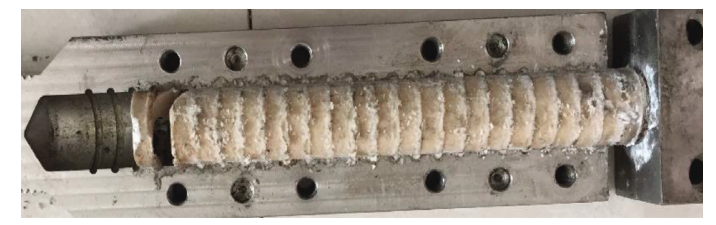

(b)

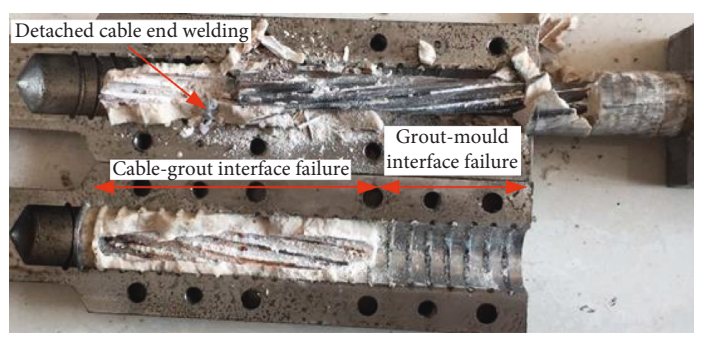

(c)

Figure 10: Three failure modes encountered in the DEPTs. (a) Typical cable-grout interface failure. (b) Grout-mould interface failure. (c) Cable end welding failure + partial grout-mould interface failure.

In general, the indented cable bolt reached a larger tensile strength at small pullout displacement than the plain cable bolt. The pullout displacement of the indented cable bolt at peak pullout force was in the range of about $3 \sim 7 \mathrm{~mm}$, whilst the pullout displacement of the plain cable bolt at peak pullout force was in the range of about $45 \sim 70 \mathrm{~mm}$. Overall, the indented cable bolt exhibited higher tensile resistance capacity than the plain cable bolt in the first $30 \sim 40 \mathrm{~mm}$ pullout displacement.

3.6. Failure Mode Effect. A typical bolting reinforcement system comprises four components: bolt, rock, internal fixture, and external fixture. All adjacent components interact and form four interactions which determine the load transfer performance of a bolting reinforcement system. In the case of DEPT, as shown in this study, there is no external fixture and the rock component is replaced by steel mould. Thus, the cable performance in DEPT is mainly determined by the cable, grout (internal fixture), cable-grout interaction, and grout-mould interaction. When failure occurs in different parts of a cable reinforcement system, the cable performance is expected to be different.

In the laboratory DEPTs, three types of failure were encountered: cable-grout interface failure, grout-mould interface failure, and cable end welding failure as shown in Figure 10. Among these three failure modes, the cable-grout interface failure was the expected failure mode, and the other two were unexpected special cases. The test results corresponding to these three failure modes are given in Figure 11.

In Figure 11, the cable bolt in DEPT with a cable-grout interface failure exhibited a typical three-stage force-displacement relationship. As for the DEPT with a grout-mould interface failure, similar to the cable-grout interface failure, the cable bolt experienced a stiff linear stage and the first softening stage initially prior to a local peak, followed by a sharp force drop. After the force drop, the cable bolt almost fully lost its tensile resistance capacity and could not take any meaningful load. This was the worst case for cable bolting,

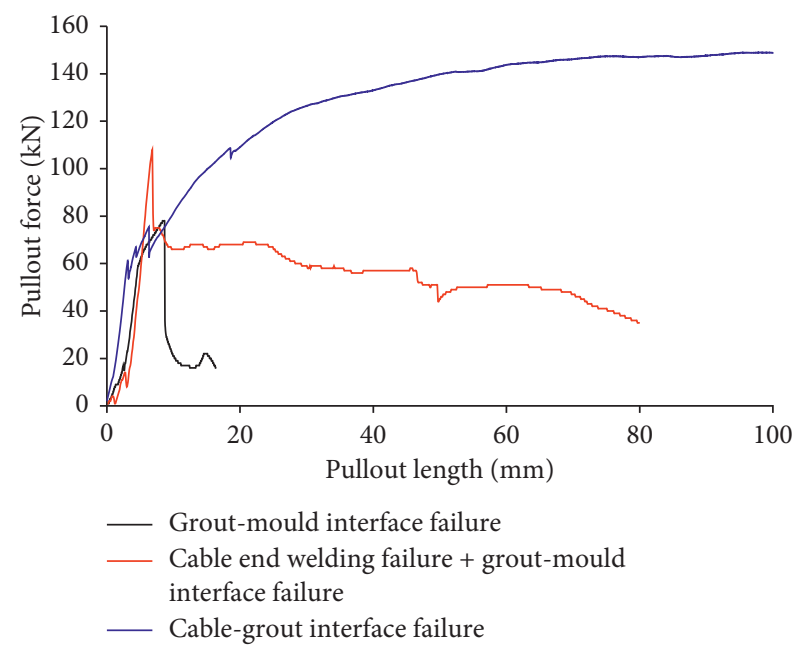

FIGURE 11: Load transfer performance of the cable bolt in DEPT of different failure modes.

which could happen in field when the borehole is very smooth or when gloving effect occurs with resin cartridge in the cable installation process. As seen in Figure 10(b), the grout was fully sheared off from the mould at the groutmould interface at very small displacement. Then, when the displacement reached the groove (steel mould) spacing of about $10 \mathrm{~mm}$, the cable bolt experienced the sharp force drop and almost fully lost its tensile resistance.

When it comes to the DEPT with a cable end welding failure and a partial grout-mould interface failure as shown in Figure 10(c), the cable bolt exhibited a behavior with a combination of the first two failure modes. To be exact, the cable bolt experienced a sharp force drop which was much larger than that of the typical cable-grout interface failure but smaller than that of the full grout-mould interface failure. This large sharp force drop might be related to the outer partial grout-mould interface failure and/or the cable end welding failure (refer to Figure 10(c)). Unlike the full 
grout-mould interface failure, the cable bolt still held the capacity of taking noticeable loads after the sharp force drop. The reason for this is that the outer part with partial groutmould interface failure completely lost its load-bearing capacity, while the grout-mould interface of the inner part still had its full load-bearing capacity. After the sharp force drop, the outer part with grout-mould interface failure would not make noticeable contribution to the pullout force, and the pullout force was almost all from the inner part without grout-mould interface failure. In this case, the cable bolt should be expected to exhibit a behavior similar to the typical cable-grout interface failure as shown in Figure 10(a). However, if we have a close check of the force-displacement curve (refer to Figure 11), it will be found that the pullout force did not go up after the sharp force drop like what happened in the typical cable-grout interface failure. In the typical cable-grout interface failure, the pullout force increased gradually after the sharp force drop due to friction and mechanical interlocking at the cable-grout interface. However, the friction and mechanical interlocking at the cable-grout interface were weakened substantially due to untwisting in the case of cable end welding failure. Thus, the pullout force decreased gradually instead of increasing in the case of cable end welding failure.

Different failure modes of cable bolting system produced different load transfer performances. In general, the cablegrout interface failure produced most reliable and preferable result. Thus, attentions should be given to the quality of cable end welding, grouting, and borehole roughness in practice to avoid the occurrence of cable end welding failure and groutrock (mould) interface failure.

\section{Conclusions and Recommendations}

Strength and stiffness are the basic load transfer characteristics of a cable bolt in tension. Double embedded pullout test is a commonly used method of obtaining cable/rock bolt load transfer characteristics. As cable bolt has a spiral structure, its load transfer characteristics are expected to be different from rock bolt. A series of DEPTs were conducted to investigate the load transfer performance of cable bolt, and the studied influencing factors include cable rotation, grout age, grout anchorage annulus thickness, cable wire profile, and failure mode. The conclusions drawn from the tests are as follows:

(1) The plain cable bolt exhibited a three-stage forcedisplacement relationship prior to gradually losing its tensile resistance capacity, whilst the indented cable bolt directly reached its final peak before gradually losing its tensile resistance capacity.

(2) Grout age only affected the tensile strength of the cable bolt, but not the basic force-displacement relationship. The older the grout, the higher the cable resistance strength.

(3) The degree of cable rotation in tension affected the cable tensile resistance strength. The larger the cable rotation, the smaller the cable tensile resistance strength.
(4) Cable-grout interface failure, grout-mould interface failure, and cable end welding failure were encountered in the laboratory tests. The force-displacement relationship of the cable bolt in tension was much affected by the failure mode. Cable-grout interface failure was preferable, followed by cable end welding failure, while the grout-mould interface failure fully damaged cable tensile resistance capacity at very small displacement, and thus, it is undesirable.

(5) Grout anchorage annulus thickness severely affected the strength and stiffness of cable bolt in tension. Thick grout anchorage annulus weakened both the cable strength and stiffness.

More work that can be done in future to deepen the understanding of load transfer of cable bolt in tension is as follows:

(1) Investigating what factors are controlling the degree of cable rotation

(2) Monitoring and evaluating the degree of cable rotation in field condition and its impact on the load transfer

(3) Analyzing the mechanism of grout anchorage annulus thickness effect and providing a method of designing an effective grout anchorage annulus thickness for a specific condition

\section{Data Availability}

The data used to support the findings of this study are included within the article.

\section{Conflicts of Interest}

The author declares no conflicts of interest.

\section{Acknowledgments}

The authors wish to thank the laboratory technician WanXin Song and group members Yanjiang Chai, Jinzheng Bai, Kunyou Zhou, Quan Liu, Xiaoqi Hao, Zepeng Han, and Yujun Sun who assisted to prepare and complete the laboratory tests. The first author wishes to thank Prof. Aziz for his instructions about test design in his study. This research was funded by the Fundamental Research Funds for the Central Universities (2018QNA30).

\section{References}

[1] Z. Zhang, J. Bai, Y. Chen, and S. Yan, “An innovative approach for gob-side entry retaining in highly gassy fully-mechanized longwall top-coal caving," International Journal of Rock Mechanics and Mining Sciences, vol. 80, pp. 1-11, 2015.

[2] K. Skrzypkowski, "Evaluation of rock bolt support for polish hard rock mines," E3S Web of Conferences.vol. 35, pp. 1-8, 2018.

[3] K. Skrzypkowski, "A new design of support for burst-prone rock mass in underground ore mining," E3S Web of Conferences.vol. 71, pp. 1-9, 2018. 
[4] X. Li, N. Aziz, A. Mirzaghorbanali, and J. Nemcik, "Behavior of fiber glass bolts, rock bolts and cable bolts in shear," Rock Mechanics and Rock Engineering, vol. 49, no. 7, pp. 2723-2735, 2016.

[5] X. Li, J. Nemcik, A. Mirzaghorbanali, N. Aziz, and H. Rasekh, "Analytical model of shear behaviour of a fully grouted cable bolt subjected to shearing," International Journal of Rock Mechanics and Mining Sciences, vol. 80, pp. 31-39, 2015.

[6] N. Aziz, A. Mirzaghorbanali, J. Nemick, X. Li, H. Rasekh, and G. Wang, "Load transfer characteristics of plain and spiral cable bolts tested in new non rotating pull testing apparatus," in Proceedings of the 16th Coal Operators' Conference, Wollongong, Australia, January 2016.

[7] P. Fuller and R. Cox, Mechanics of Load Transfer from Steel Tendons to Cement Based Grout. Division of Applied Geomechanics, CSIRO, Canberra, Australia, 1975.

[8] J. M. Goris and J. P. Conway, "Grouted flexible tendons and scalling investigations," in Proceedings of the 13th World Mining Congress, World Mining Congress, Stockholm, Sweden, 1987.

[9] R. D. Reichert, A Laboratory and Field Investigation of the Major Factors Influencing Bond Capacity of Grouted Cable bolts, Master's thesis, Queen's University, Kingston, Canada, 1991.

[10] A. J. Hyett, W. F. Bawden, R. Powers, and P. Rocque, Innovative Mine Design for the 21st Century, Archibald, Ed., CRC Press, Boca Raton, FL, USA, 1st edition, 1993.

[11] A. J. Hyett, W. F. Bawden, and N. Hedrick, "The $25 \mathrm{~mm}$ Garford bulb anchor for cable bolt reinforcement," Cim Bulletin, vol. 88, pp. 54-59, 1994.

[12] G. R. Macsporran, An Empirical Investigation into the Effects of Mine Induced Stress Change on Standard Cable Bolt Capacity, Master's thesis, Queen's University, Kingston, Canada, 1993.

[13] S. Stillborg, Experimental Investigation of Steel Cables for Rock Reinforcement in Hard Rock, Ph.D. thesis, Luleå University of Technology, Luleå, Sweden, 1984.

[14] D. J. Hutchinson and M. S. Diederichs, Cable Bolting in Underground Mines, BiTech Publishers, Richmond, Canada, 1996.

[15] R. Thomas, "The load transfer properties of post-groutable cable bolts used in Australia coal industry," in Proceedings of the 31st International Conference on Ground Control in Mining, Morgantown, MV, USA, July-August 2012.

[16] B. Clifford, L. Kent, P. Altounyan, and D. Bigby, "Systems used in coal mining: developments in long tendon reinforcement," in Proceedings of the 20th International Conference on Ground Control in Mining, Morgantown, MV, USA, August 2001.

[17] P. Hagan, J. Chen, and S. Saydam, "The load transfer mechanism of fully grouted cable bolts under laboratory tests," in Proceedings of the 14th Coal Operators' Conference, Wollongong, Australia, February 2014. 


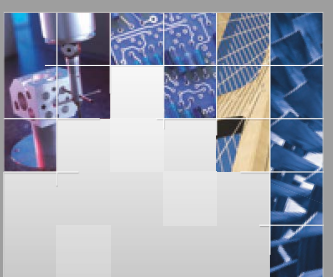

\section{Enfincering}
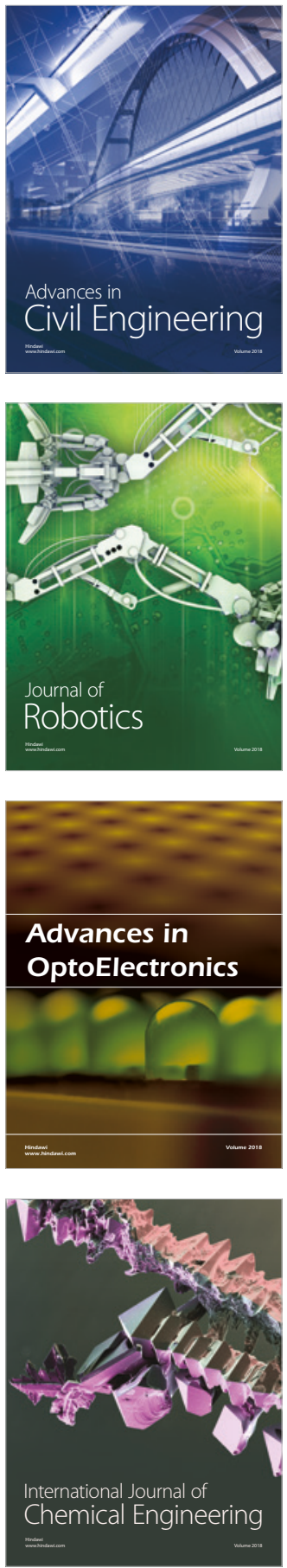

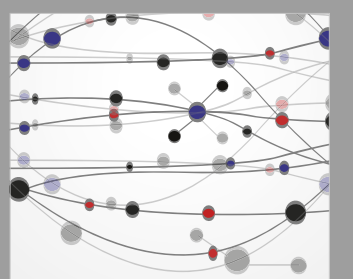

\section{Rotating \\ Machinery}

The Scientific World Journal

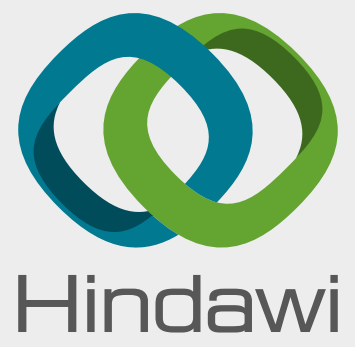

Submit your manuscripts at

www.hindawi.com
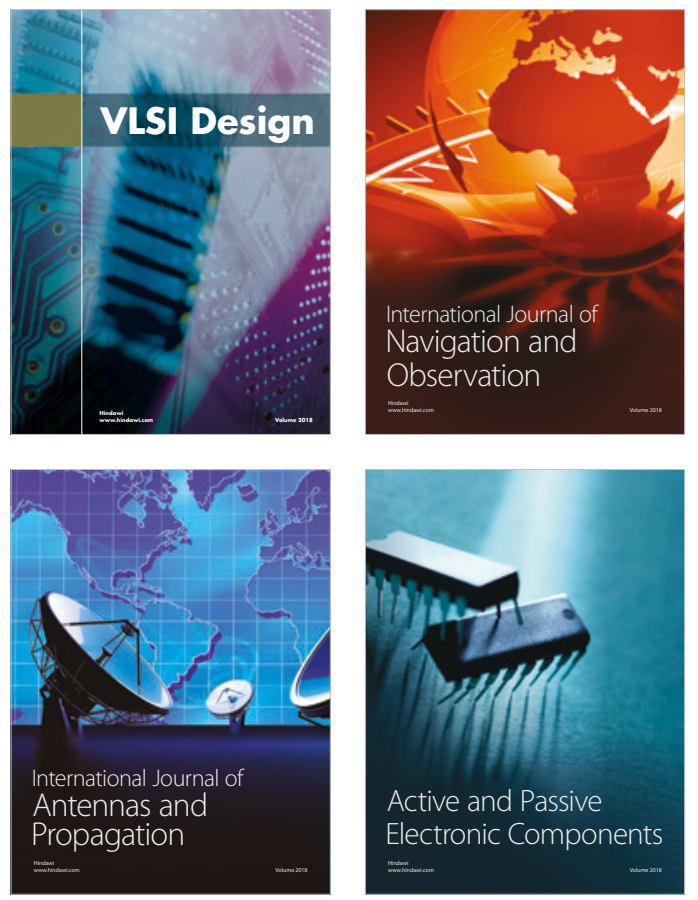
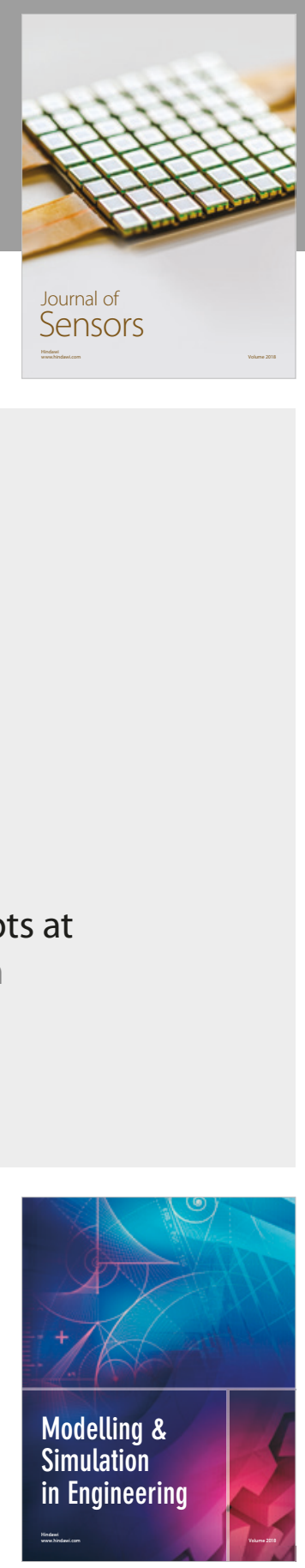

\section{Advances \\ Multimedia}
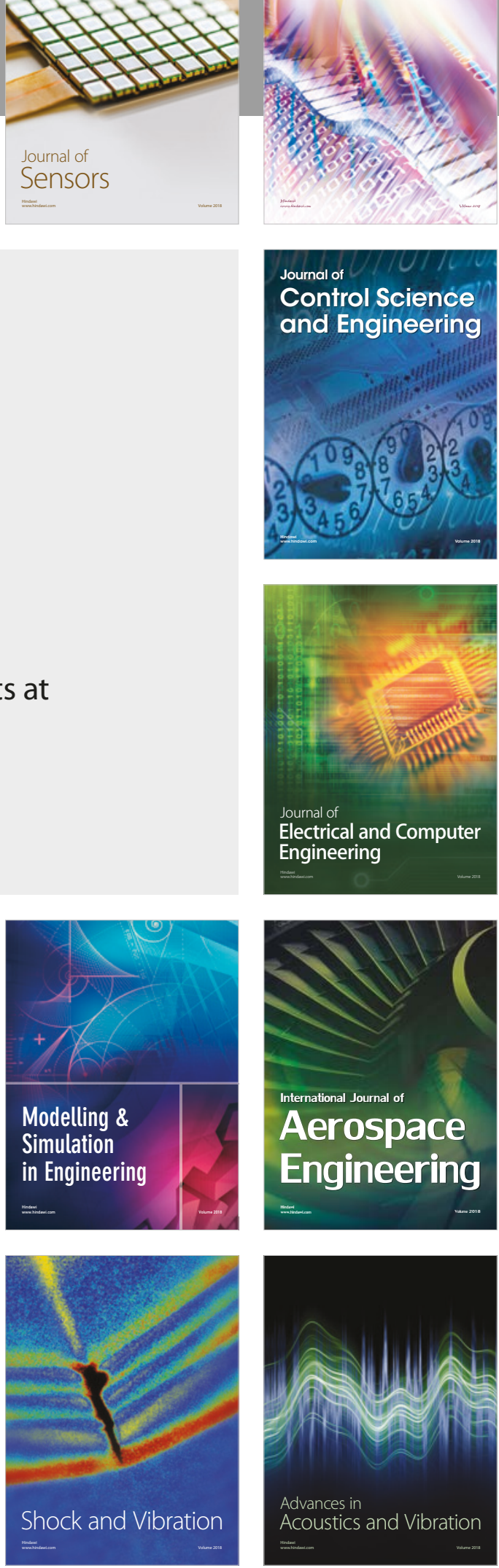